\title{
Sözlük bilimi açısından değer taşıyan eserler: Osmanlı dönemi tıp kitapları
}

\section{Mücahit AKKUȘ2}

\begin{abstract}
APA: Akkuş, M. (2019). Sözlük bilimi açısından değer taşıyan eserler: Osmanlı dönemi tıp kitapları.
\end{abstract} RumeliDE Dil ve Edebiyat Araştırmaları Dergisi, (15), 99-115. DOI: 10.29000/rumelide.580482

\section{$\ddot{O} \mathbf{z}$}

Tıp, çok eski çağlardan günümüze kadar gelen önemli bir bilim dalıdır. Bu bilim dalının gelişimini görmek için çağlar boyunca yazılmış eserlerin incelenmesi gerekmektedir. İlaçlardan hastalık adlarına kadar kullanılan tıp terimleri, tarihî tıp araştırmaları açısından son derece değerlidir. Bu bilgiler, tıp alanındaki değişimi ve ilerlemeyi de gösterecektir. Türk dilinin farklı dönemlerinde yazılmış tıp kitapları bu değişimi gösterir niteliktedir. Bu dönemlerden bir tanesi de Osmanlı dönemidir. Osmanlı döneminde yazılmış tıp kitapları dil yönünden önemli bir yere sahiptir. Bu kitaplar, gerek tıp terimlerini gerekse de o dönemin günlük konuşma dilini göstermesi bakımından oldukça zengindirler. Bir kelimenin birçok dilde karşılığının verilmesi bu zenginliği arttırmaktadır. İşte bu durum sözlük bilimi araştırmacıları için verimli bir alan oluşturmaktadır. Çünkü kullanılan ve başka dilde karşılı̆̆ı verilen her kelime, sözlük bilimi çalışmalarına bir katkı sağlayacaktır. Tıp metinlerinin içerisinde sözcüğün başka dildeki karşılığının verilmesinin yanında terimlerin tanımları yapılmakta ve bu tanımlar farklı açıklamalarla desteklenmektedir. Bu sebeple üslubu farklı olsa da her metin kendi içerisinde bir sözlük mahiyeti kazanmaktadır. Bu durum günümüzde yazılan tıp terimleri sözlükleri için de değerlidir. Çalışmada Osmanlı döneminde yazılmış tıp metinleri incelenecektir. Bilhassa 15. ve 19. yüzyıllar arası yazılmış tıp metinlerinde sözcük dağarcı ̆̆ değerlendirilecektir. Aynı zamanda bu eserlerin Türkçe sözlük çalışmalarına ne gibi katkı sağlayacağı tartışılacaktır.

Anahtar kelimeler: Sözlük bilimi, tıp, Osmanlı.

\section{The works that are important for lexicology: Ottoman medical books}

\begin{abstract}
Medicine is an important science since ancient times. In order to see the development of this discipline, the works written throughout the ages should be examined. Medical terms used from drugs to disease names are very valuable for historical medical research. This information will also show the change and progress in the medical field. Medical books written in different periods of the Turkish language indicate this change. One of these periods is Ottoman period. Medical books written during Ottoman period have an important place in terms of language. These books are rich in terms of both medical terms and the daily spoken language of that period. The equivalent of a word in many languages increases this wealth. This is an efficient field for lexicography researchers. Because every word used and given in another language will contribute to dictionary studies. In medical texts, the definitions of the terms are made in addition to the equivalence of the word in another language and these definitions are supported by different explanations. For this reason, although the style is
\end{abstract}

Bu çalışma 14-17 Şubat 2019 tarihlerinde Yalova'da düzenlenen Uluslararası Bilimsel Araştırmalar Kongresi'nde sözlü bildiri olarak sunulmuştur.

2 Öğr. Gör. Dr., Hitit Üniversitesi, Fen-Edebiyat Fakültesi, Türk Dili ve Edebiyatı Bölümü (Çorum / Türkiye), mucahitakkuso1@hotmail.com, ORCID ID: 0000-0003-0375-2198 [Makale kayt tarihi: 05.05.2019-kabul tarihi:16.06.2019; DOI: 10.2900o/rumelide.580482] 


\begin{abstract}
different, each text is a dictionary in itself. This situation is also valuable for medical dictionaries written today. In this study, the medical texts written during the Ottoman period will be examined. Especially vocabulary will be evaluated in medical texts written between $15^{\text {th }}$ and 19 th centuries. At the same time, the contribution of these works to Turkish dictionary will be discussed.
\end{abstract}

Keywords: Lexicology, medicine, Ottoman.

\title{
Giriş
}

Türklerde sözlük çalışmalarının ilki Kaşgarlı Mahmud tarafından gerçekleştirilmiş ve yazmış olduğu Divân-ı Lugat-it Türk çağlar sonrasını aydınlatmıştır. Daha sonra Harezm-Kıpçak, Çağatay Türkçesi dönemlerinde de çok önemli eserler meydana getirilmiştir. Mukaddimetü'l-Edeb, Muhakemetü’lLugateyn bunlardan sadece bazılarıdır. Bu durum batı sahasında da süregelmiş, Eski Anadolu Türkçesi ve Osmanlı Türkçesi devirlerinde sözlük çalışmaları zamanın dilini yansıtmaları bakımından önem arz etmiştir. Günümüzde ise o devirlerin söz varlı̆̆ının daha iyi anlaşllabilmesi için tarihî sözlükler oluşturulmuştur. Özellikle Türk Dil Kurumu tarafından hazırlanmış başta Türkçe Sözlük olmak üzere birçok farklı alanda sözlük çalışması gerçekleştirilmiştir.

Sözlükçülük önemli bir alandır. Yazılmış bir eserin daha iyi anlaşılabilmesi için anlam kavramı öne çımmaktadır. Bilhassa Türkçede kelimelerin temel anlamının yanında yan anlamlarının ve mecaz anlamlarının olduğunu düşünürsek sözlük çalışmalarının ne derece önem arz ettiğini daha iyi anlamış oluruz. Bir kelimenin tarih içerisindeki anlam değişimleri de bu konu içerisinde değerlendirilebilir. Çünkü bir sözcügün geçen asırlar ile aynı olmayıp farklı anlamlar kazanması doğaldır. İşte bu ve bu gibi sebeplerle anlam bilimi, sözlük bilimi gibi alanlar daha çok önem kazanmaktadır. Sözlük bilimi; bir dilin veya karşılaştırmalı olarak çeşitli dillerin söz varlığını sözlük biçiminde ortaya koyma yöntemlerini ve uygulama yollarını gösteren dil bilimi dalı (Korkmaz 1992: 140) olarak tanımlanır. Sözlük bilimi alanının daha iyi incelenmesi ve anlaşılması için eskiden günümüze hazırlanan sözlüklerin içerikleri yeterince gözden geçirilmelidir. Aslında yazılmış her metnin sözlük bilimi alanına katkı sağlayacak bir yönü vardır. Edebi eserlerin edebiyat sözlüklerine, tarih metinlerinin tarihî sözlüklere katkısı olacaktır.

Burada farklı alanlarda yazılmış sözlük çalışmaları ön plana çıkmaktadır. Her konu kendi için bir uzmanlık alanı gerektirir ve her uzmanlık alanı konusu sözlük bilimi için değerlidir. Uzmanlık alan sözlükleri denince akla gelen, terim sözlükleridir. Dilde sosyolekt adı verilen özellikle mesleklere dayanan belli grupların, belli kesimlerin dilini yansıtan sözlükler, belli bir alanın bütün terimlerini bir araya getirir; eğitimde ve bilimsel çalışmalarda yardımcı ve uzlaştırıcı olur (Aksan 1982: 83). Felsefe konusunda yazılan eserlerde felsefe bilimine ait sözcük dağarcı̆̆ı, tıp alanında yazılan eserlerde tıp alanına ait sözcük dağarcığı bulmak mümkündür. İşte bunlardan elde edilen veriler sayesinde sözlükler yapılmakta ve sözlük bilimi için katkı sağlayacak ortam oluşmaktadır. İncelenen alan hangisi olursa olsun o alandaki terimlerin bir araya getirilmesi gereklidir. Terim sözlükleri, yalnızca terim niteliği taşıyan ögeleri içermekte, bunların başka dillerdeki karşılıklarını, tanımlarını ve gerekli açıklamaları vermektedir (Aksan 1982: 83). Doğan Aksan'ın bu açılaması tarihî tıp terimlerinin oluşumundaki aşamaları birebir gösterir niteliktedir. Bu metinlerde tanımlar yapılmakta, diğer dillerdeki karşılıkları verilmektedir. Tanımlar konuyla ilgili farklı açıklamalarla desteklenmektedir. Hatta bir terimin aynı dil içindeki farklı kullanımlarını da görmek mümkündür.

Burada Anadolu sahasında bilhassa Osmanl döneminde tıp biliminin nasıl bir seyir izlediğinden de bahsetmek yerinde olacaktır. Anadolu'da tıp çalışmaları Eski Anadolu Türkçesi döneminde başlamıştır. 
Osmanlı sahasında Klasik tıp anlayışı ortaya çıkmış, 17. ve 18. asırlar itibariyle de batıdaki tıp anlayışı daha yoğun bir şekilde takip edilmeye başlanmıştır. Selçuklular döneminden itibaren açılan darüşşifalar Osmanlı sahasında çoğalmış ve tıp biliminin birçok alt koluyla birlikte insan sağllğı için çalışmalar yürütülmüş̧ür. Darüşşifalarda hekimler yetiştirilmiştir. Tıp eğitiminde mantık ve klasik tıp kitapları okutulmuş, tıbbın temeli kabul edilen anatomi Galenus ve İbn Sînâ'nın eserlerinden takip edilmiştir. (Bayat 2016 : 297). 14. yüzyıl itibariyle tıp alanıyla ilgili eserler de verilmeye başlanmıştır. İshak bin Murad'ın Edviye-i Müfrede adlı eseri, yazılmış ilk tıp kitaplarına bir örnektir. Bu eserin yanında çağlar boyunca tıp bilimine katkı sağlayacak yüzlerce yeni eser yazılmaya devam etmiştir. Siyâhî Karamanî Larendevînin Mecmâ-i Tıp adlı eseri, Tabîb İbn-i Şerîfin Yâdigâr adlı eseri, Şerefeddin Sabuncuoğlu'nun Terceme-i Akrabâdîn adlı eseri, Hekim Bereket’in Tuhfe-i Mübarizi adlı eseri, Celâlüddin Hızır (Hacı Paşa)'nın Müntahab-ı Şifâ adlı eseri, Şirvanlı Mahmud'un Kemâliyye adlı eseri yazılmış birçok telif ve tercüme eserden sadece birkaçıdır. Eserlerde farmakolojiden cerrahi bilimlere kadar farklı konular ele alınmıştır. İlerleyen zamanlarda Avrupa'yla temas hâlinde veya Avrupa dillerinden birine vakıf olan hekimler, Batı'daki yeni tıp anlayışını temsil eden eserleri tercüme ederek veya buralardan yaptıkları alıntılara kendi yorumlarını katarak tıbbî eserler kaleme almaya başlamışlardır (Bayat 2016: 319). Elbette ki bu eserlerin her biri kendi içinde zengin bir dil malzemesi içermektedir. Aşağıda ele alınan örnekler bilhassa sözcük dağarcığı açısından ortak ve benzer noktaları görmek bakımından önemli olacaktır.

\section{Tıp metinlerinin sözlük bilimine katkıları}

Tıp metinlerinin genel bir özelliği vardır. O da hemen hemen her tıp metninin kendi içinde bir tıp terimleri sözlüğü niteliğinde olmasıdır. Anlatım üslubu, konusu, metni sunuş tarzı, manzum ya da nesir özelliğinde yazılmış olması az çok farklılık oluşturabilir. Ancak az sonra da ele alınacak metin örneklerinden de görüleceği gibi terimlerin Türkçe, Arapça, Farsça, Yunanca, Latince vd. dillerdeki karşıllğı bu metinlerde verilmektedir. Bu durum, çoğu kelimenin anlamını günümüzde yazılmış herhangi bir sözlüğe bakma ihtiyacı duymadan bulabilme imkânı vermektedir. Böyle bir durumda metnin okunuşu ve yorumlanışı daha akıcı bir şekilde olacaktır. Bazı örneklerde sadece kelime karşılığı verilirken bazı örneklerde kelimelerin tanımı verilmiştir. Bazı örneklerde ise tanımın yanında ayrıntılı bir şekilde o terime dair açıklamalar da bulunulmuştur. Aşağıdaki örnekler sözlük bilimi adına daha belirgin hâle gelmesi için tek sıralı tablolar halinde desteklenmiştir. Bu tablolarda bir terimin kelime karşılı̆̆ı, tanımı, açıklanma şekli vb. örnekler gösterilmektedir. Tıp metinlerinde kullanılan söz varlığı için uygulanan metot farklı şekillerde ortaya çıkmaktadır. Bu makalede Osmanlı sahasında yazılmış tıp kitapları içerisinden seçilmiş metinlerin örnekleri bulunmaktadır. Aşağıda kelimelerin anlamının ve açıklanmasının hangi yöntemlerle ele alındığı alt başlıklar hâlinde değerlendirilmiştir:

\section{"ya' ni kelimesi ile açıklama"}

Örneklerin birçoğunda “ya`ni” ifadesi kullanılmıştır. Bu ifadeyle birlikte terimlerin açıklanacağı, o konu hakkında bilgi verileceği anlaşılmaktadır.

ziyt ile nāne ya 'ni itmege ḳașr itmesin sipāriş eyledi (Tercüme-i Ebubekir er-Râzi: 97b)³

\begin{tabular}{|l|l|}
\hline nān & itmek \\
\hline
\end{tabular}

3 Metin örneklerinin yanında hangi eserden alındı̆̆ı ve varak numarası verilmiştir. Metinler üzerinde çalışan kişiler ise kaynakça bölümünde gösterilmiştir. Yine kaynakçada bulunan eserlerin sözlük kısımlarından da yararlanılmıştır.

Adress

Kirklareli University, Faculty of Arts and Sciences, Department of Turkish Language and Literature, Kayalı Campus-Kırklareli/TURKEY e-mail: editor@rumelide.com 
102 / RumeliDE Journal of Language and Literature Studies 2019.15 (June)

The works that are important for lexicology: Ottoman medical books / M. Akkuş (p. 99-115)

Açılama: Burada zeytin ve ekmeğin birlikte tüketilmesi tavsiye edilmektedir.

buḳl mıșrda hindubāya dérler ya 'ni acı mārūl ve göyinek dah̆ dérler (Lügat-1 Müşkilât-1 Eczâ: 9b)

\begin{tabular}{|l|l|l|l|}
\hline buḳl & hindubā & acı mārūl & göyinek \\
\hline
\end{tabular}

Açılama: Burada bukl terimine karşılık gelen diğer terimler belirtmiştir.

ey țâlib bilmiş olasın ve ḩafakânı ya'ni yürek énmesi giderür ve cāna rāḥat verür (Mücerreb-nâme: 4b)

\begin{tabular}{|l|l|}
\hline hafaḳān & yürek énmesi \\
\hline
\end{tabular}

Açıklama: Burada, kullanılan bir ilacın kalp daralmasına iyi geleceği belirtilmiş.

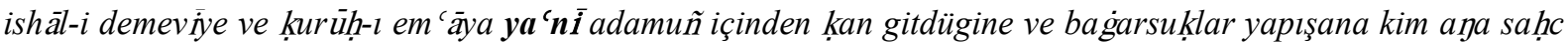
dérler (Terceme-i Akrabâdîn: 30/b)

\begin{tabular}{|c|c|c|}
\hline ishāl-i demevìve kurüh̆-ı em 'ā & $s a h c$ & adamuñ içinden ḳan git- ve bağarsuḳları yapış- \\
\hline
\end{tabular}

Açıklama: Burada sahc terimi açıklanmış olup kan ve bağırsak sorunundan bahsedilmektedir.

ayaklarun altı sahc ola ya'nī derisi gitse cirāhat olsa alasın (Mücerreb-nâme: 34b)

\begin{tabular}{|l|l|}
\hline ayaḳlarun altı sahc ol- & derisi git- cirāhatat ol- \\
\hline
\end{tabular}

Açıklama: Burada sahc kelimesinin deri soyulması anlamına geldiği belirtilmektedir.

ayruk gelmeye ammā a gizda hùn olsa ya 'ni diş etleri çürise (Müntehib: 112b)

\begin{tabular}{|l|l|}
\hline ag̀zzda hǜ ol- & diş etleri çüri- \\
\hline
\end{tabular}

Açıklama: Ağızda hūn olmasının karşılığı olarak diş etlerinde çürüme meydana gelmesi verilmiştir.

Selesü’l-bevl olmak, ya'nì tíz tíz șu dökmek marażlarınuñ sebeblerin ve devāların beyān ider (Kemâliyye: 12b)

\begin{tabular}{|l|l|}
\hline Selesü'l-bevl olmak & tíz tíz șu dökmek \\
\hline
\end{tabular}

Açıklama: Selesü’l-bevl hastalığının bevli (idrarı) tutamama rahatsızlığı olduğu ifade edilmektedir.

\section{"denir, derler... kelimeleriyle destekleme"}

Bu örneklerde doğrudan denir, denilir, derler... ifadeleri kullanılarak tanım yapılmıştır.

mastakî: Yûnânîden mu'arrebdir. Arapça kiye ve 'ilk-i Rûmî dahi derler. Türkçe sakız derler. (Risâle-i Feyziyye fî̀ Lügâti'l-Müfredâti't-Tibbiyye: M bölümü)

\begin{tabular}{|l|l|l|l|}
\hline mastakî & kiye & 'ilk-i Rûmî & sakız \\
\hline
\end{tabular}

Açıklama: Burada mastaki sözcüğünün Yunanca, Arapça, Rumca ve Türkçe karşılığı verilmiştir. 
oglancıklar hastalıgına kim arabca kitablarda ümmü's-sıbyân derler sar'a nev'indendir (Yâdigâr: 227a)

\begin{tabular}{|l|l|}
\hline & \\
oglancıklar hastalıgı & ümmü's-sıbyân \\
\hline
\end{tabular}

Açıklama: Ümmü’s-sıbyan hastalığının küçük çocuklarda görülen bir hastalık olduğunu ve beyinle ilgili bir rahatsızlık olduğu belirtilmiş.

bir direm antimun Türkce demirbozan didikleridir (Gāyetü'l-Muntehā fi-Tedbïü'l-Merzā: 27a)

\begin{tabular}{|l|l|}
\hline antimun & demirbozan \\
\hline
\end{tabular}

Açıklama: Antimun ifadesinin demirbozan olarak kullanıldığını belirtmiş.

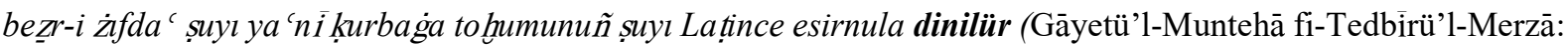
94a)

\begin{tabular}{|l|l|l|}
\hline bežr-i żlda`șuyl & kurbag்a tohumunuñ șuyl & esirnula \\
\hline
\end{tabular}

Açıklama: Esirmula ifadesinin kurbağa tohumunun suyu olarak geçtiğini belirtmiş.

Aña curt curt öten dér Türkçe herkes

Ufacuḳ dölegi biridür ol pes (Mecmâ-i Tıp: 30b)

\begin{tabular}{|l|l|}
\hline cirt cirt öten & Ufacuk döleg \\
\hline
\end{tabular}

Açıklama: Burada dölegi ifadesiyle kavun kastedilmektedir.

\section{"ki/ kim kullanılarak tanım ve açıklama yapma"}

Bir terim hakkında bilgi vermek amacıyla ki/kim bağlaçları kullanılmıştır.

şol biti kim derinüñ üstinde yapışur aya türkce ḳrkayaḳlu dérler (Terceme-i Akrabâdîn: 234b)

\begin{tabular}{|l|l|}
\hline derinüñ üstinde yapış- & kırkayaḳlu \\
\hline
\end{tabular}

Açılama: Burada kırkayaklu ifadesiyle deriye yapışan bir cins kurtçuk olduğu belirtilmiştir.

șag eli ri'şe olmış ya'ni ditremiş şöyle kim eli nesne țutmaz olmış (Mücerreb-nâme: 26a)

\begin{tabular}{|l|l|l|}
\hline ricşe ol- & ditre- & eli nesne tutmaz ol- \\
\hline
\end{tabular}

Açıklama: Burada kişinin sağ elinde bir titreme olduğu ve elinde kuvvetin olmadığı vurgulanmış.

zıfra bir gışâdır kim yufkacık et sûretlü gözün bınârından biter uzanur yürür zamânile bebegi örter görmez eyler yufkası olur ve kalını olur arabca zıfra dirler parisice nâhna dirler ada ve âdemde olur (Yâdigâr: 137a)

\begin{tabular}{|l|l|l|l|}
\hline zıfra & nâhna & gözün binârından bit- & bebegi ört-görmez eyle- \\
\hline
\end{tabular}


Açıklama: Burada, zıfranın göz pınarlarında oluşan ve göz bebeğine kadar yerleşen bir tür yara olduğu belirtilmiştir.

slfat-l huften (uyku)

nef'i budur kim tene rāḥat vérür

mi 'dede komaz ța 'āmı sigirür (Tabiatnâme: 18b)

\begin{tabular}{|l|l|l|}
\hline șlfat-ı huften & tene rāhat vér- & ta'āmı sigir- \\
\hline
\end{tabular}

Açıklama: Burada huftenin insanı rahatlattığı, midenin sindirimini kolaylaştırdığı belirtilmiş.

yılan sarımsagi ki țag்da biter büyük sarımsaḳdur ıssıdur tīzdür andan biraz yeseler öksürügi keser (Müntahab-1 Şifâ : 71a,71b)

\begin{tabular}{|l|l|l|}
\hline yllan sarımsaġ & tagda bit- & öksürügi kes- \\
\hline
\end{tabular}

Açılklama: Burada belirtilen sarımsak çeşidinin dağlarda yetiştiği ve öksürüğe iyi geldiği belirtilmiş.

\section{“İçerisinde lisan/dil ismi geçen örneklerle destekleme”}

$\mathrm{Bu}$ örneklerde terimlerin hangi dillerde nasıl kullanıldığı belirtilmiştir.

Anuñ bir adı Türkçe burma dérler

Dénülür ḳurluġan hem aña ekșer (Mecmâ-i Tip: 26a)

\begin{tabular}{|l|l|}
\hline burma & kurlugian \\
\hline
\end{tabular}

Açılama: Burada burma ifadesine kurlugan da denildiği belirtilmiş.

hader didikleri 'illet ki türkīide uyuşuḳluk dirler (Tercüme-i Ebubekir er-Râzi: 13a)

\begin{tabular}{|l|l|}
\hline hader & uyuşuḳluk \\
\hline
\end{tabular}

Açılama: Ḩader ifadesinin Türkçe karşılığı uyuşukluk olarak belirtilmiş.

şancārdur 'arabca ḩassü'l-ḥımār dérler türkce eşek mārülıdur (Terceme-i Akrabâdîn: 274/b)

\begin{tabular}{|l|l|l|}
\hline şancār & hassü'l-ḥmāàr & eşek mārüll \\
\hline
\end{tabular}

Açılama: Şancar ifadesinin Türkçe ve Arapça karşıllğı verilmiştir.

cevz: Fârisiden mu'arrebdir. Arapça hasf ve Yûnânca kâsîlis ve Mısrîler şûbekî derler. Cevz lafž mutlak zikr olunsa murâd cevz-i Rûmîdir ki avam tahrif edip ceviz ve Türkçe zamm ile koz derler. (Risâle-i Feyziyye fî Lügâti'l-Müfredâti't-T1bbiyye: C)

\begin{tabular}{|l|l|l|l|l|}
\hline cevz & hasf & kâsîlis & şûbekî̀ & koz \\
\hline
\end{tabular}


Açıklama: Cevz sözcüğünün Farsça, Arapça, Yunanca, Türkçe karşılıkları belirtilmiştir.

hayrî meşhûr otdur kim türkçe misir benefşesi dirler ve parisice şebboy dirler benefşe renklüsi gice kokdugundan ötrü şebboy dirler ve sarusu ve beyâzı gündüz kokar (Yâdigâr: 140a)

\begin{tabular}{|l|l|l|}
\hline hayrî & misır benefşesi & şebboy \\
\hline
\end{tabular}

Açıklama: Mısır benefşesinin Farsça karşılığı verilmiş, kokusunu gece verdiği için şebboy adını aldı ̆̆ından bahsedilmiştir.

yüzerlik; ki 'arabca adı ḥarmeldür, issidür ḳurudur, yapraginn dögüp aya ḳ ağrısina vursalar fãyide éder (Edviyei Müfrede: $5 b$ )

\begin{tabular}{|l|l|}
\hline yüzerlik & harmel \\
\hline
\end{tabular}

Açıklama: Burada yüzerliğin yaprağının ayak ağrılarına iyi geleceği belirtilmiş.

baldırı ḳara; ki färsīce persiyāvşan dérler bir otdur, sular çevleginde biter, yapraġ kerefes yapragina betzzer (Edviye-i Müfrede: 11a)

\begin{tabular}{|l|l|}
\hline baldırı ḳara & persiyā v̧san \\
\hline
\end{tabular}

Açıklama: Burada baldırı kara yaprağının kerefes yaprağına benzediği belirtilmiştir.

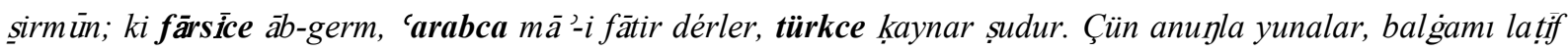
éder (Edviye-i Müfrede: 13a)

\begin{tabular}{|l|l|l|l|}
\hline sirmün & äb-germ & mà -i fätir & ḳaynar șu \\
\hline
\end{tabular}

Açılama: Sirmūn, balgamı söken bir özelliğe sahiptir.

\section{“Sadece kelime karşılı̆̆ı verilen örnekler"}

Buradaki örneklerde bir tanım cümlesi yerine terimlerin farklı kullanım şekilleri belirtilmektedir.

Dah̆ ḳugun otı bir adı serhes

Aña ayrıltt dérler Türkçe herkes (Mecmâ-i Tıp: 12a)

\begin{tabular}{|l|l|l|}
\hline kuzgun otı & serhes & ayriltı \\
\hline
\end{tabular}

Açıklama: Ayrıltı ifadesinin tıptaki başka kullanımlarından bahsetmiş.

Örneklerde Türkçe karşılığı olarak farklı dillerden örnekler verilmektedir. Bazen de Türkçe bir kelime farklı yörelerde kullanılış şekliyle gösterilmektedir.

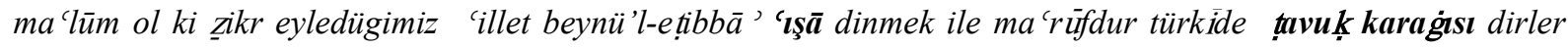
(Tercüme-i Ebubekir er-Râzi: 21a)

\begin{tabular}{|l|l|}
\hline 'ışā & țavuḳ karagìsl \\
\hline
\end{tabular}


Açıklama: Tip çevresinde kullanılan 'ışā ifadesinin tavuk karagusı (tavuk karası) olarak geçtiği belirtilmiş.

şaḳika ki beynen-nās yarım baş a grısı dimegile meşhurdur (Tercüme-i Ebubekir er-Râzi: 7b)

\begin{tabular}{|l|l|l|}
\hline şaḳika & beynen-nās & yarım baş a grrısı \\
\hline
\end{tabular}

Açıklama: Şakiḳa, ifadesinin Türkçede hafif baş ağrısı olduğu belirtilmiş.

gözlerinde ve lisānında șufret ya 'ni șarılıḳ yoḳ idi (Tercüme-i Ebubekir er-Râzi: 4a, 4b)

\begin{tabular}{|l|l|}
\hline sufret & sarllık \\
\hline
\end{tabular}

Açıklama: Kişinin gözlerinde ve dilinde sarılık hastalığı olmadığı belirtilmiştir.

żmād yaḳu ma'nāssnadır (Tercüme-i Ebubekir er-Râzi: 5a)

\begin{tabular}{|l|l|}
\hline zimād & $y a k ̣ u$ \\
\hline
\end{tabular}

Açıklama: Burada yak- fiilinden türeyen yaku kelimesinin żımād olarak kullanıldığı belirtilmiş.

büsre sivilci dimekdür (Tercüme-i Ebubekir er-Râzi: 5a)

\begin{tabular}{|l|l|}
\hline büsre & sivilci \\
\hline
\end{tabular}

Açıklama: Sivilci (sivilce) kelimesinin büsre olarak kullanıldı̆̆ı belirtilmiş.

eskââuzuza didikleri otdur ki Türkce aña eşek otı dirler bayırlarda olur (Gāyetü'l-Muntehā fi-Tedbïrü'l-Merzā: 22b)

\begin{tabular}{|l|l|}
\hline esḳāpüza & eşek otı \\
\hline
\end{tabular}

Açıklama: Burada eşek otu adlı bitkinin tepelere yakın yerlerde olduğu belirtilmiş.

būsîrdir ki șigirknuyrugi didikleri otdur (Gāyetü'l-Muntehā fi-Tedbirü'l-Merzā: 22b)

\begin{tabular}{|l|l|}
\hline büsir & slgigrḳuyrugi \\
\hline
\end{tabular}

Açıklama: Sığırkuyruğu otunun būsīi olarak geçtiği belirtilmiş.

entüle Türkide peygamber dügmesi dirler (Gāyetü'l-Muntehā fi-Tedbïrü'l-Merzā: 22b)

\begin{tabular}{|l|l|}
\hline entüle & peyg்amber dügmesi \\
\hline
\end{tabular}

Açıklama: Entüle kelimesinin karşılığının peygamber düğmesi olduğu belirtilmiş.

ferāsiyun ki Türkide it siyegi dirler (Gāyetü'l-Muntehā fi-Tedbïrü'l-Merzā: 73b)

\begin{tabular}{|l|l|}
\hline ferāsiyun & it siyegi \\
\hline
\end{tabular}

Açıklama: Ferāsiyun kelimesinin karşıllı̆ının it siyegi olduğu belirtilmiş. 
șlfat-l ayāric-i fayḳarā yūnān lug̉atında fayḳarā démek acı démek olur (Terceme-i Akrabâdîn: 87b)

\begin{tabular}{|l|l|}
\hline fayḳarā & acı \\
\hline
\end{tabular}

Açıklama: Faykara kelimesinin karşıllı̆ının acı olduğu belirtilmiş.

a hyūn yılan başı dérler yemişi dah̆ı a ya beyzer (Lügat-1 Müşkilât-1 Eczâ: 3b)

\begin{tabular}{|l|l|}
\hline ahyuùn & yllan başı \\
\hline
\end{tabular}

Açıklama: Ahyūn kelimesinin yılan başı olarak kullanıldığı belirtilmiş.

hem alnina ve tuluñlarına kim arabça şakîka derler dürteler gayetde râhat olub hararet teskîn ola (Yâdigâr: 221b)

\begin{tabular}{|l|l|}
\hline tuluñ & şakika \\
\hline
\end{tabular}

Açılama: Tuluñ kelimesinin şakîka olarak geçtiğini belirtmiş.

sigirde: her ulaşuḳ ayrılmaḳ-kim sinirde ola 'arabca a pa rażżdérler ya 'nỉ üzilmek (Tuḥfe-i Mübārizì: 22b)

\begin{tabular}{|l|l|l|}
\hline sigirde & rażż & üzilmek \\
\hline
\end{tabular}

Açıklama: Sijir ifadesinin üzülmek anlamında olduğu belirtilmiş.

\section{"Doğrudan tanım cümleleri ile oluşanlar"}

Buradaki örneklerde ele alınan terimlerin tanımları yapılmaktadır.

şiryān diyü ḥareket iden tạmarlara dirler ḥareket itmeyen tạmarlara verīd dirler

(Tercüme-i Ebubekir er-Râzi: 7a)

\begin{tabular}{|l|l|}
\hline şiryān & hareket iden tamarlar \\
\hline verid & hareket itmeyen tamarlar \\
\hline
\end{tabular}

Açıklama: Şiryān ve verìd kelimelerinin anlamları hareket eden ve hareket etmeyen damar olarak belirtilmiş.

'anz keçiniñ ve yaban keçisiniñ ve geyigiñ dişisine dirler (Tercüme-i Ebubekir er-Râzi: 20b)

\begin{tabular}{|l|l|}
\hline 'anz & keçiniñ ve yaban keçisiniñ ve geyigiñ dişisi \\
\hline
\end{tabular}

Açılama: ‘anz kelimesi keçinin ve geyiğin dişisi olarak tanımlanmış.

tafşîl dimek mercimek aşına dirler kim sirke ile pişüreler (Yâdigâr: 228a)

\begin{tabular}{|l|l|}
\hline taf̧şll & mercimek aşı \\
\hline
\end{tabular}


Açıklama: Tafşîl kelimesinin karşıllı̆ı mercimek aşı olarak belirtilmiş olup sirke ile pişirilmesi tavsiye edilmiş.

bir dürlü uyuzıçün sürük ola ana keçi uyuzı dèrler (Müntahab-1 Şifâ : 129b)

\begin{tabular}{|l|l|}
\hline keçi uyuzı & bir dürlü uyuzıçün sürük ol- \\
\hline
\end{tabular}

Açıklama: Keçi uyuzu, bir uyuz çeşidi olarak belirtilmiş.

\section{“Tanım ve açıklama örnekleri”}

Bu örneklerde terimler üzerinde yapılan tanımlar ve açıklamalar görülmektedir. Tanım ve açılamalar arka arkaya yapılmıştır. Bazı örneklerde tanım verilirken yanlarında konuyla ilgili kısa açıklamalar da yapılmıştır. Bazılarında ise geniş açıklamalara yer verilmiştir.

'Arabca aña salhüi'l-ḥayya dérler

Yılan ḳavlar birag̉ur anı ekșer (Mecmâ-i Tip: 29a)

\begin{tabular}{|l|l|}
\hline salhü'l-hayya & Yllan ḳavlar bıra $\dot{g}_{-}$ \\
\hline
\end{tabular}

Açıklama: Salhü’l-hayya kelimesinin açıklaması yılan derisi olarak belirtilmiş.

rub` 'ssttmasına ya'nīiki gün țutmayub üçünci gün țutan ısitmaya fãyide eyler (Mücerreb-nâme: 13b)

\begin{tabular}{|l|l|}
\hline$r u b^{c}$ & iki gün thutmayub üçünci gün țutan tsitma \\
\hline
\end{tabular}

Açılama: Rub` kelimesi bir sıtma çeşidi olarak belirtilmiş.

şahm: Hayvanın iç yağıdır. Tlbbda şahm mutlak zikr olunsa murâd keçinin iç yağıdır. (Risâle-i Feyziyye fî Lügâti'l-Müfredâti't-Tıbbiyye: Ş bölümü)

\begin{tabular}{|c|c|c|}
\hline şahm & Hayvanın iç yağl & keçinin iç yağl \\
\hline
\end{tabular}

Açıklama: Şahm kelimesinin karşılı̆̆ hayvandaki iç yağ olarak belirtilmiş.

bașākü'l-ḳamer ay tạşı dérler 'arab diyārnda ay atarken bulurlar (Lügat-1 Müşkilât-1 Eczâ: 10b)

\begin{tabular}{|l|l|l|}
\hline bașākü 'l-ḳamer & ay țassı & ay atarken bulun- \\
\hline
\end{tabular}

Açıklama: Bașāḳü’l-ḳamerin ay çıktı̆̆ında bulunabileceği belirtilmiş.

mā 'ü'l-ḥadīd demürciler demir șog̉uddug̉ șudur (Lügat-1 Müşkilât-1 Eczâ: 48b)

\begin{tabular}{|l|l|}
\hline mā $\dddot{u}$ 'l-ḥadid & demürciler demir șo ġudduğ $s u$ \\
\hline
\end{tabular}

Açıklama: Mā'ü'l-ḥadīd ifadesinin demir soğutulan su olduğu belirtilmiş.

yédi gün 'alile veresin muḳayyi ya'nỉ ḳuṣdurucı 'alīle veresin içe (Mücerreb-nâme: 38b) 


\begin{tabular}{|l|l|}
\hline mukayyi & kușdurucı 'alile \\
\hline
\end{tabular}

Açılama: Burada muḳayyi kelimesinin kusturma özelliği olan bir ilaç olduğu belirtilmiş.

şol ḳuşun yağını kim ol ḳuşa șār dérler devlüngeçden bir nev`dür (Mücerreb-nâme: 43b)

\begin{tabular}{|l|l|}
\hline$s ̦ a ̄ r$ & devlüngeçden bir nev \\
\hline
\end{tabular}

Açıklama: Bir kuş türü olan șār, devlüngeç çeşidi olarak belirtilmiş.

hammâmın haslyeti budur ki bedenin fazlaların tahlîl ider ve deriyi arıdır ishâli kat' ider meşâmları ya'nî der çılkacak yerleri açar (Yâdigâr: 37b)

\begin{tabular}{|l|l|}
\hline meşâm & der çıkacak yerler \\
\hline
\end{tabular}

Açıklama: Burada meşâm kelimesi vücuttaki terin çıtığı yerler olarak belirtilmiş.

teşennüc sinir büzülmesine dirler ve küzâz sinir katımasına dirler ve kurulmasına dirler teşennüc iki dürlüdür birisi mâdde ile bir def'ada olur ve birisi az az olur (Yâdigâr: 131b)

\begin{tabular}{|l|l|l|}
\hline teşennüc & sinir büzülmesi & birisi mâdde ile bir def'ada olur ve birisi az az olur \\
\hline küzâz & sinir katımast & sinir kurulmast \\
\hline
\end{tabular}

Açıklama: Teşennücün iki türlü olduğu ve anlamının sinirlerin büzülmesi olduğu belirtilmiş diğer yandan küzāz, sinirlerin katılaşması olarak belirtilmiştir.

zefnību dah̆ rüm dilincedür ve 'arabca şeceret'l-gàr dérler issidür ḳurudur, șovuḳdan olan șayrulıḳara yarar. (Edviye-i Müfrede: 17a)

\begin{tabular}{|l|l|l|l|}
\hline Zefnī & șeceret'l- $\dot{g} \bar{a} r$ & issi, ḳuru & $\begin{array}{l}\text { șovuḳdan olan } \\
\text { șayrulıklara yarar }\end{array}$ \\
\hline
\end{tabular}

Açılama: Zefninin soğuk algınlığına iyi geldiği belirtilmiş.

Üçünci nev'e Yünāniler usturyūs dirler; ma 'nāsl, kevkebì dimek olur ve bu nev' yeşmüñ̃ cismi șaḳildür, içinde ak tamarlar olur. (Tuhfe-i Murâdî:92b)

\begin{tabular}{|l|l|l|}
\hline usturyūs & kevkebī & içinde ak tạmarlar ol- \\
\hline
\end{tabular}

Açıklama: Usturyūsun içinde ak damarlar olduğu belirtilmiş.

Ü̧̧ünci nev'üñ̃ zebercedinüñ rengi mu'tedil durur, ya'nì rengi ne ḳatı tọk ve ne ḳat yaşıl durur (Tuhfe-i Murâdî:51a)

\begin{tabular}{|l|l|}
\hline mu'tedil & rengi ne ḳatı tọk ve ne ḳatt yaşıl \\
\hline
\end{tabular}

Açıklama: Mu'tedil, ortası manasında kullanılmış ve rengi için ne açık ne de koyu yeşil olduğu belirtilmiş. 


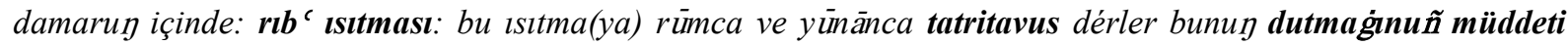
yigirmi dört sā'at olur (Tuḥfe-i Mübārizìi:24a)

\begin{tabular}{|l|l|l|}
\hline$r l b `$ ısıtması & tatritavus & müddeti yigirmi dört $s \bar{a}^{`} a t$ \\
\hline
\end{tabular}

Açıklama: Rıb` ifadesi yirmi dört saat boyunca devam eden bir sıtma türü olduğu belirtilmiş.

içinde yıyırısa ol ısıtmaya lașḳa dérler ya 'ni yaşlığ çoḳ olur eger balgam țamardan țaşra yıyırısa andan olan ısitmaya nābiye dérler kim her gün dutar (Tuhfe-i Mübārizì: 24a)

\begin{tabular}{|l|l|l|}
\hline lașka & içinde yıyırısa & yaşlığ çoḳ \\
\hline nābiye & balğam țamardan țaşra yıyırısa & her gün dut- \\
\hline
\end{tabular}

Açıklama: Lasḳa ve nābiye ifadelerinin iki farklı sıtma türü olduğu belirtilmiş.

duz ıssıdur, ḳurudur, eti ḳatı eyler ve balg̈amı gevdeden arıdur ve galìz yaşlıḳları giderür (Edviye-i Müfrede: 16b)

\begin{tabular}{|l|l|l|l|}
\hline duz & eti ḳatı eyle- & balgamı gevdeden arıt- & galìzyaşlı k̦ları gider- \\
\hline
\end{tabular}

Açıklama: Duz ifadesinin yani tuzun özellikleri sayılmış, balgam söktürücü olduğu belirtilmiştir.

yaraḳān-ı așfar ya 'ni göz ve gevdeye k̦aralıḳ düşmek sebebi șafrā çoḳlığ ve sevdā çoḳlığ ya cigerile öd arasında ya ödile bağarsuk arasında ya cigerile talak̦ arasında ya talağıla ma'de arasında südde olmakdur (Müntahab-1 Şifâ: $80 b$ )

\begin{tabular}{|c|c|c|c|}
\hline $\begin{array}{l}\text { yarakān-ı } \\
\text { asfar }\end{array}$ & $\begin{array}{l}\text { göz ve gevdeye } \\
\text { karalık düşmek }\end{array}$ & $\begin{array}{l}\text { șafrā çoḳliğ ve sevdā } \\
\text { çoḳlığ }\end{array}$ & $\begin{array}{l}\text { cigerile öd arasında ya ödile bagarsuk } \\
\text { arasında ya cigerile țalak arasında ya talagila } \\
\text { ma'de arasında südde olmak }\end{array}$ \\
\hline
\end{tabular}

Açıklama: Yarakān-ı asfar, göz kararmasıdır, burada vücutta safra ve sevdanın çokluğu nedeniyle organlar arasındaki sıkıntı anlatılmaktadır.

Kütahya şehrinde ve Bilecik'de meşhûrdur çetük otı derler muhabbet içün isti 'mâl iderler kitâblarda felenc-i müssk diyü zikr olunan edviye budur sâdece bedel bu iki çetük otunun birin ideler tenb̂̂l yaprağın itmeyeler (Yâdigâr: 65a)

\begin{tabular}{|l|l|l|}
\hline çetük otı & felenc-i müşs & Kütahya şehrinde ve Bilecik'de meşhûr \\
\hline
\end{tabular}

Açıklama: Çetük otunun Kütahya ve Bilecek şehirlerinde bilindiği, iki türlü olduğu ve birinin kullanılması gerektiği belirtilmiş.

slfat-ı zencebil

çün anı ma'cūn édeler bal-ıla

beyzi balgamdan gerek șäfi ḳla (Tabiatnâme: 12a)

\begin{tabular}{|l|l|}
\hline șfat-ı zencebil & beIzzi balgamdan gerek șäfí ḳl- \\
\hline
\end{tabular}


Açılama: Sıfat-ı zencebilin bal ile macun edilen bir bitki olduğu ve balgamdan arındırdığı belirtilmiş.

\section{"Benzetme ögeleriyle açıklananlar"}

gibi-bigi, benzer, misil, müşabih... benzetme edatları kullanılarak örnekler zenginleştirilmiştir.

gàariḳūn, ḳațān köpügidür, mantar gibi aġacda biter ammā eyüsi ki müsta'meldür Menteşe vilāyetinde arduc ağacinda biter, issidür, kurudur, sovuḳ sayrulıḳlara ve talaḳ rencine muväfiḳdur. (Edviye-i Müfrede: 27b)

\begin{tabular}{|l|l|l|}
\hline gàrikịūn, & katrāan köpügi & mantar gibi aǵacda bit- \\
\hline
\end{tabular}

Açıklama: Ġārikūun adlı bitkinin ağaçlarda yetiştiği, Menteşe'de olduğu ve soğuk algınlığına iyi geldiği belirtilmiş.

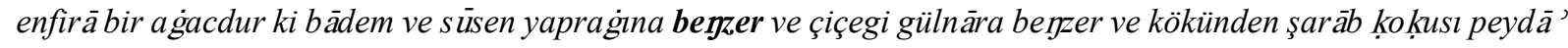
olur (Lügat-1 Müşkilât-1 Eczâ: 7a)

\begin{tabular}{|l|l|l|}
\hline enfirā & bādem ve süsen yaprağ̀na belıze- & çiçegi gülnāra belyze- \\
\hline
\end{tabular}

Açıklama: Enfirā ağacının benzediği diğer ağaç ve çiçekler belirtilmiş aynı zamanda kökünde de kokusu olduğu ifade edilmiştir.

ak ve yeni eyü sûrincân üç direm ve buzeydân üç direm kim attarlarda olur eğri kestâne dedikleri otun değirmîsine kim kestaneye müşâbeheti vardır sûrincân derler (Yâdigâr: 58b)

\begin{tabular}{|l|l|}
\hline sûrincân & kestaneye müşâbeheti vardır \\
\hline
\end{tabular}

Açıklama: Sûrincânın, attarlada da bulunduğu, kestaneye benzer olduğu belirtilmiştir.

ikinci nev'e tibnì dirler, rengi șaman rengine beñzer, ya'ni renginde az șaruluḳ bulınur (Tuhfe-i Murâdî:12a)

\begin{tabular}{|l|l|l|}
\hline & & \\
tibni $\bar{i}$ & șaman rengine beñze- & șaruluḳ \\
\hline
\end{tabular}

Açılkama: Tibnī kelimesinin sarı renkli, saman rengine benzer olduğu belirtilmiş.

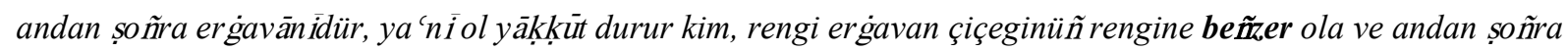

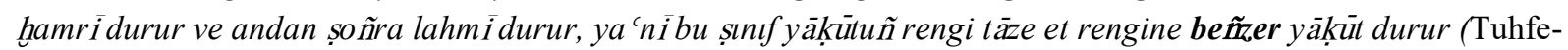
i Murâdî:32b)

\begin{tabular}{|l|l|l|}
\hline erğavānī & yākkūit & er gavan çiçeginüñ rengine beñze- \\
\hline hamrī & lahmī & tāze et rengine beñze- \\
\hline
\end{tabular}

Açıklama: Yakut çeşitlerinden bahsedilmiştir. Erguvan çiçeğine benzeyenlerin ya da taze et rengine benzeyenlerin olduğu belirtilmiştir.

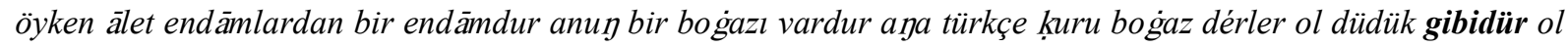
yalumuz nefes yolıdur (Tuhfe-i Mübārizi: 15a)

\begin{tabular}{|l|l|l|}
\hline öyken & kuru bog gaz & düdük gibi \\
\hline
\end{tabular}


Açıklama: Öyken yani akciğerin nefes yoluyla ilgili olduğu belirtilmiş, düdüğe benzetilmiştir.

şol incecük țtamarlar (içinde sürüp) iletmek içündür kim ol ince țamarlara şa'rí dérler ya'nì ḳl gibi țamar.. (Tuhfe-i Mübārizi: 7b)

\begin{tabular}{|l|l|l|}
\hline & & \\
ince tamar & şa $r \bar{i}$ & ḳl gibi țamar \\
\hline
\end{tabular}

Açılklama: İnce damarların şa‘ rỉ olarak adlandırıldı̆̆g ve kıla benzetildiği belirtilmiş.

A ġac südlügeni cānā Türkce ol

Süd aġacı misillidür o şekil (Mecmâ-i Tip: 30b)

\begin{tabular}{|l|l|}
\hline Aǵac südlügeni & Süd aǵacı misilli \\
\hline
\end{tabular}

Açıklama: Sütleğen otunun ağaçlarda yetiştiği bilgisi verilmektedir.

enl-i șarūn ekin aralarında biter yaprağ noḥüd yapraginna beñzer ve yemişi keci boynızına benzer icinde dāneleri olur (Lügat-1 Müsskilât-1 Eczâ: 4a)

\begin{tabular}{|l|l|l|l|}
\hline enl-i șarün & ekin aralarında bit- & yaprağı noḥüd yapragina beñze- & $\begin{array}{l}\text { yemişi keci boynızına } \\
\text { benze- }\end{array}$
\end{tabular}

Açıklama: Enl-i sarūn ifadesinin taneleri olan, ekin aralarında yetişen bir bitki olduğu belirtilmiş. beyzi ḳarasag̉u ola ve nabżı kiriş bigi ola (Kitâbü'l-Mühimmat: 11b)

\begin{tabular}{|l|l|}
\hline nabżı & kiriş bigi \\
\hline
\end{tabular}

Açıklama: Kişinin benzinde ve nabzında meydana gelen değişiklikler aktarılmıştır.

\section{"Tanım ve açıklama amacı olmadan verilen örnekler"}

Verilen örneklerde doğrudan ifadenin tanımının yapılması amacı yoktur. Tanım yapılmadan gerçekleşen durum anlatılmıştır.

bir yigit bir sene ķadar dam 'aya mübtelā olup gözlerinden yaş aķar imiş (Tercüme-i Ebubekir er-Râzi: 22b)

\begin{tabular}{|l|l|}
\hline $\operatorname{dam}^{\prime} a$ & gözlerinden yaşak,- \\
\hline
\end{tabular}

Açıklama: Dam`anın gözden yaş akma hastalığı olduğu belirtilmiş.

żarb bir nev' kirpi adama oḳ atar ve bala da h̆ı démişler (Lügat-1 Müşkilât-1 Eczâ: 33b)

\begin{tabular}{|l|l|l|l|}
\hline żarb & nev'kirpi & okat- & bala \\
\hline
\end{tabular}

Açıklama: Żarbın bir kirpi çeşidi olduğu ve ok atma özelliği olduğu belirtilmiş. 


\section{"Her iki tarafın da cümle olarak verilmesi"}

Örnekler bir kelimenin açıklanması şeklinde değil de kelime gruplarının ya da cümlelerin karşılaştırılması şeklinde gerçekleştirilmiştir.

bir kimseye șudā' 'ārı̇̇ olup bașarı zā'il olmuş ya'ni gözi görmez olmuş (Tercüme-i Ebubekir er-Râzi: 7b)

\begin{tabular}{|l|l|}
\hline bașarl zāंil ol- & gözi görmez ol- \\
\hline
\end{tabular}

Açıklama: Sudā hastalı̆̆ının gözlerin görmeme hastalığı olduğu belirtilmiş.

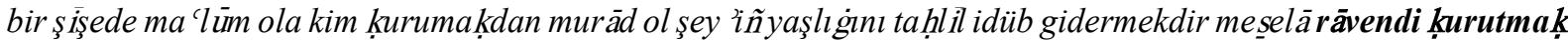
ruṭübet-i müshilesi gitsün aräyyesi kalsun dimekdir (Gāyetü'l-Muntehā fi-Tedbīü’l-Merzā: 26b)

\begin{tabular}{|l|l|}
\hline rāvendi kurutmaḳ & ruțübet-i müshilesi gitsün arz̈yyesi kalsun dimek \\
\hline
\end{tabular}

Açıklama: Burada sulu, yaşlı, nemli olan bir maddenin örnekleme yoluyla suyunun alınması ve toprağının kalması, kuru hâle gelmesi anlatılmıştır.

\section{“Örneklendirmeler yoluyla anlatma”}

Bahsedilen konu hakkında genellikle "meselā" ifadesi kullanılarak örnek verilme yoluna gidilmiştir.

evvelkiden ḳalil meșelā dişlere uyuşma getürmeyecek ḳadar olduḳda ma '̈̈'l-anisōn ile ü̧̈ dirhem gülbeşeker isti 'māline müdãvemet eyleye (Tercüme-i Ebubekir er-Râzi: 44b)

\begin{tabular}{|l|l|}
\hline meselāa & dişlere uyuşma getürmeyecek kadar ol- \\
\hline
\end{tabular}

Açılama: Dişlere uyuşma gelmemesi için kullanılması gereken ilacı örneklendirmiştir.

ol birbirine karışan nesne degül meșelā toprag̉ suya ḳarlşdursalar şöyle kim șu țopraġa ve topraḳ șuya gey fi 'il ve eser eylese ol iki arasindan balçuk zāhir olur (Tuḥe-i Mübārizi: 6a)

\begin{tabular}{|l|l|}
\hline meselāā & toprağ suya ḳarışdur- \\
\hline
\end{tabular}

Açıklama: Burada su ve toprağın birbirine karıştığında ortaya çıkan balçık anlatılmaktadır.

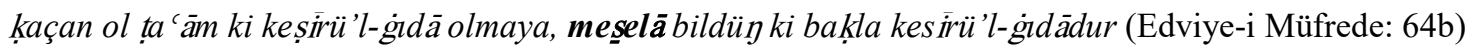

\begin{tabular}{|l|l|}
\hline meșelā & baḳla kesirü'l-ğgdādur \\
\hline
\end{tabular}

Açıklama: Burada baklanın yoğun bir gıda olduğu örneklendirilmektedir.

\section{Sonuç ve öneriler}

Yukarıda ele alınan belli başlı örnekler de açıkça göstermektedir ki, tarihî tıp metinlerinin söz varlığı çok ayrı bir çalışma alanı gerektirmektedir. Sadece bu örneklerden yola çıkarak metinlerin sözlük bilimi ve anlam bilimi için ne kadar değerli olduğu söylenebilir. Birçok yabancı kelimenin Türkçe karşılı̆̆ının verilmesi, birçok terimin tanımının yapılması, terimlerin özelliklerinin açıklanması vd. hususlar ortaya konan örneklerin ne derece zengin dil malzemesi içerdiğinin kanıtıdır. Bu terimleri cümle içinde görmek 
örneklerin daha kolay anlaşılmasını sağladığından yazılacak tarihî tıp terimleri sözlüklerinin cümle örnekli olması gerektiği kanaatindeyiz.

Cümle örnekli tarihî tıp terimleri sözlüğü, terimlerin açlklanmasında ve anlaşılmasında yardımcı olacak niteliktedir. Bu durumun Tarama ve Derleme sözlükleri için de ayrı bir yeri olacaktır. Tıp metinleri farklı dillerin terim dağarcığını da gözler önüne sermesi bakımından değerlidir. Bunun yanında hekimlerin o dönemde ne kadar farklı dil terminolojisine hâkim olduklarının da bir göstergesidir. Tıp metinlerinde geçen ifadelerin günümüz Anadolu sahasında ne kadarının kullanılıp kullanılmadığı da ayrı bir çalışma alanı olabilir. Bilinmektedir ki, sayılan onlarca bitki ismi, hastalık ismi, organ ismi günümüz Anadolu sahasında varlığını sürdürmektedir. Gerek dil zenginliği, gerekse de halkbilimi ögelerinin zenginliği nedeniyle tıp metinleri bir proje dâhilinde tekrardan ele alınmalı, geniş kapsamlı Tıp Terimleri Söz varlığı çalışmaları yapılmalıdır.

\section{Kaynakça}

Akkuş, M. (2008). Siyâhî Karamanî Larendevînnin Mecmâ-i Tıp Adlı Eseri (Gramer-Metin-Sözlük), Erciyes Üniversitesi Sosyal Bilimler Enstitüsü Türk Dili ve Edebiyatı Ana Bilim Dalı Yüksek Lisans Tezi, Kayseri.

Akkuş, M. (2018). Ali Münşi’nin Tercüme-i Ebubekir er-Râzi Adlı Eseri (Söz Dizimi ve Anlambilim İncelemesi), Kırıkkale Üniversitesi Sosyal Bilimler Enstitüsü Türk Dili ve Edebiyatı Ana Bilim Dalı Doktora Tezi, Kırıkkale.

Aksan, D. (1982). Her Yönüyle Dil, Ana Çizgileriyle Dilbilim, Ankara: Türk Dil Kurumu.

Altınbaş, A.; Saki, O. (2003). Tabîb İbn-i Şerîf Yâdigâr, İstanbul: Merkez Efendi ve Halk Hekimliği Derneği, Yerküre.

Altınbaş, A.; Okutan, Y. vd. (2004). Tabîb İbn-i Şerîf Yâdigâr, İstanbul: Merkez Efendi ve Halk Hekimliği Derneği, Yerküre.

Argunşah, M. (1999). Muhammed b. Mahmûd-ı Şirvânî Tuhfe-i Murâdî (İnceleme-Metin-Dizin), Ankara: Türk Dil Kurumu.

Bayat, A.H. (2016). Tip Tarihi, İstanbul: Zeytinburnu Belediyesi

Canpolat, M; Önler, Z. (2016). İshak bin Murâd - Edviye-i Müfrede, Ankara: Türk Dil Kurumu

Dinar, T. (2013). Muderris Hasan Efendi'nin “Gāyetü'l-Muntehā fi-Tedbīrü'l-Merzā”sı (Hastalıkların Tedavisinde En Son Nokta) (İnceleme-Metin-Dizinler), Pamukkale Üniversitesi Sosyal Bilimler Enstitüsü, Türk Dili ve Edebiyatı Ana Bilim Dalı Doktora Tezi, Denizli.

Doğan, Ş. (2009). Terceme-i Akrabâdîn Sabuncuoğlu Şerefeddin (Giriş-İnceleme-Metin-Dizinler), Sakarya Üniversitesi Sosyal Bilimler Enstitüsü Türk Dili ve Edebiyatı Ana Bilim Dalı Doktora Tezi, Sakarya

Doğan, Ş. (2012). Ebulfeyz Mustafa Efendi Risâle-i Feyziyye fî Lügâti’l-Müfredâti’t-Tıbbiyye, İstanbul: Değişim.

Doğuer, B. E. (2013). Hekim Bereket Tuhfe-i Mübarizi (Metin-Sözlük), Ankara: Türk Dil Kurumu.

Şahin H. (2007). Abdulvehhāb Yūsuf ibn-i Ahmed el-Mārdāni - Müntehib, Bursa: Uludağ Üniversitesi.

Karasoy, Y. (2018). Tutmacı, Tabiatnâme, Ankara: Türk Dil Kurumu.

Küçüker, P. (2010). Mücerreb-nâme Şerefeddin Sabuncuoğlu, Ankara: Kültür Ajans.

Korkmaz, Z. (1992). Gramer Terimleri Sözlüğü, Ankara: Türk Dil Kurumu.

Murad, S. (2009). Lügat-ı Müşkilât-ı Eczâ Derviş Siyâhî Lârendevî (Giriş-İnceleme-Metin-Dizinler), Sakarya UUniversitesi Sosyal Bilimler Enstitüsü Türk Dili ve Edebiyatı Ana Bilim Dalı Yüksek Lisans Tezi, Sakarya. 
Önler, Z. (1990). Celâlüddin Hızır (Hacı Paşa) Müntahab-ı Şifâ (Giriş - Metin), Ankara: Türk Dil Kurumu Yainları.

Özçelik, S. (2001). Kitabü’l-Mühimmât, Ankara: Atatürk Kültür Merkezi Başkanlığı.

Parlatır, İ. (2009). Osmanlı Türkçesi Sözlüğü, Ankara: Yargı.

Türkçe Sözlük. (2005). Ankara: Türk Dil Kurumu.

Yelten, M. (1993). Şirvanlı Mahmud - Kemâliyye, İstanbul: İstanbul Üniversitesi Edebiyat Fakültesi. 